\title{
ALÉM DA ÓBVIA, EXISTIRÁ OUTRA QUÍMICA QUE A COMPLEMENTA, NEM QUE SEJA PELA ATRACÇÃO OU PELA REACÇÃO ÀS COISAS MAIS PROSAICAS E MUNDANAS DA VIDA
}
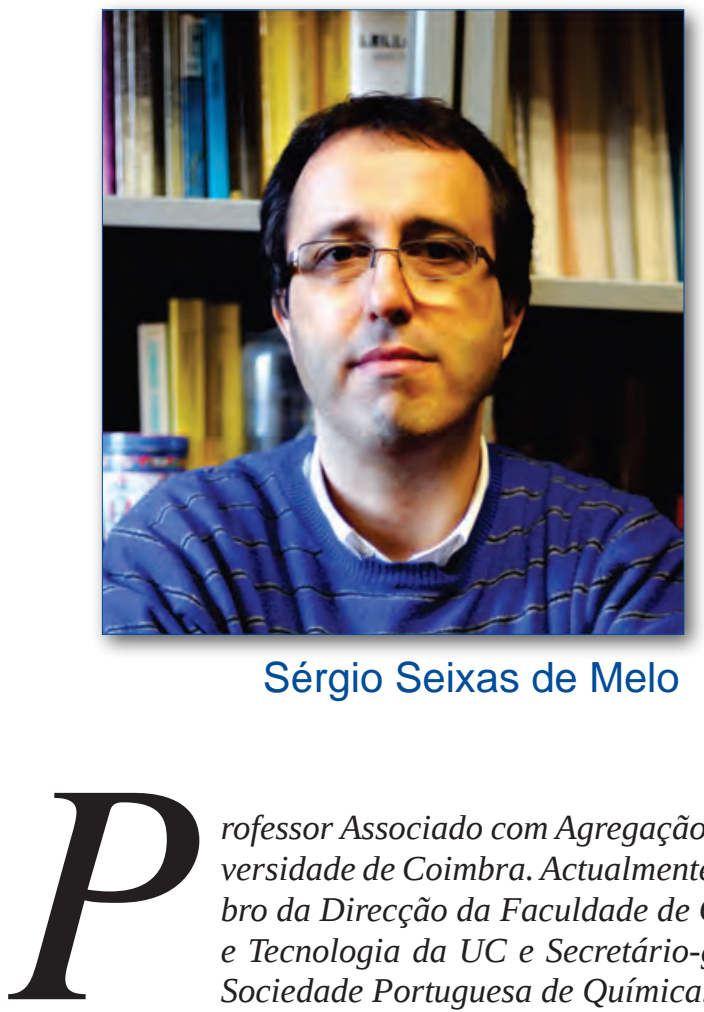

rofessor Associado com Agregação na Universidade de Coimbra. Actualmente é membro da Direcção da Faculdade de Ciências e Tecnologia da UC e Secretário-geral da Sociedade Portuguesa de Química.

Os seus interesses científicos incidem sobre a fotoquímica e fotofísica de moléculas e a Química e a Arte. Possui mais de 150 publicações científicas (ISI) e diversos outros trabalhos de índole pedagógica e de actividades de divulgação científica, nelas se incluindo as Olimpíadas de Química Júnior.

Faço uma espécie de interlúdio. Isto parece um daqueles inquéritos de verão que se fazem às "personalidades" na praia. Se bem que quando respondo a este questionário, ainda é verão, quando sair no QUÍMICA, já não o será. Tomarei a liberdade de responder com boa disposição, como se quer num destes inquéritos. Mas isto merecia uma entrevista presencial. Com vista para o Mondego ou Tejo. Os rios das minhas cidades.

\section{ENTREVISTA}

Indique lugares, livros, músicas, filmes e actividades performativas da sua preferência ou que mais o marcaram até hoje.

Quando me fazem estas perguntas costumo normalmente indicar os livros que li mais recentemente e daqueles que me recordo bem. Há, no entanto, uma diferença entre os livros de leitura de cabeceira e os que a profissão de (foto) químico induz.

Os livros clássicos de Gabriel García Márquez são sempre uma referência. Pela simplicidade e facilidade de construir uma história sempre verosímil mas romanceada, talvez por ter sido um jornalista. Dois que reli recentemente: "Crónica de uma Morte Anunciada” e o "Relato de um Náufrago” (baseado numa história verídica).
Mas ficaria de mal comigo se não falasse de autores portugueses que marcaram a minha infância e adolescência. Pelo menos um. E pouco (?) conhecido: José Gomes Ferreira. Não o jornalista Editor de economia da SIC, mas o autor de ficção, contos, poesia, etc. Dois livros que ainda me lembro (mais do primeiro; um rapaz que vivia na terra do chora-que-logo-bebes): “Aventuras Maravilhosas de João Sem Medo” e “O Enigma da Árvore Enamorada”. Mas também me relembro bem do livro "Platero e Eu" de Juan Ramón Jimenez. E como leitor feroz de BD, não posso deixar de referir (quase) toda a BD francófona, e em particular Gaston Lagaffe, Iznogoud, Tintin, Astérix ou Blake e Mortimer (de E. P. Jacobs, agora com novos autores), Bernard Prince, Benoit Brisefer (o menino super-forte que perde a força quando constipado).

E já agora dois de ciência. A primeira versão do livro de N. J. Turro “(Molecular Photochemistry”) e do livro de R. S. Becker ("Theory and Interpretation of Fluorescence and Phosphorescence”) ambos de quando a fotoquímica dava os seus primeiros passos a sério! Que estimulante devem ter sido esses tempos! E como reaprendemos a fotofísica nesses livros.

Filmes: Tantos... dois então: “As Férias do Senhor Hulot” de Jacques Tati e "Era Uma Vez na América” de Sérgio Leone. Em ambos os filmes a música é sublime e encontra-se numa perfeita simbiose com o filme. As histórias (muito diferentes) mexem com o (meu) interior.

E já agora uma série de TV dos anos 1970: "Fawlty Towers”. O humor inglês em todo o seu esplendor! Único!

Atividades performativas?! Bom, não sei bem o que responder. Nunca fiz teatro, nunca cantei, pintura também não, por isso o mais que se aproxima foi a altura em que fui filatelista. Até premiado. Fez-me, tal como Steve Jobs dizia no seu memorável discurso na Universidade de Stanford, “you only connect the dots at the end”, ligar os pontos com a mauveína de Perkin num estudo em selos do tempo da Rainha Vitória (um trabalho publicado este ano).

Isto dos lugares remonta a imaginários próprios que demoraria muito a explicar. Como em tudo ficam aqui dois muito gerais: Sintra e São Pedro do Sul. Com saudades do futuro, em locais e com pessoas ainda por conhecer.

Entre a multiplicidade de tarefas que necessita de fazer no dia-a-dia qual é aquela em que sente que o processo de transferência de energia para a realizar é o mais eficiente? E o menos eficiente?

Hum, isto de Transferência de Energia leva-nos a outras transferências: de protão ou de eletrão. Na multiplicidade de modos de desativação do estado excitado que é o dia-a-dia, todas são efetuadas com perda de energia não radiativa (escura!). Aquele em que o processo de TE é mais eficiente é aquele que se prende com as solicitações da FCTUC, SPQ e aulas. Tantos emails (e o que eles contêm!) por dia. E se não houvesse email? Como era mesmo há 20 anos atrás? Lembram-se? 